\title{
A Case of Squamous Cell Carcinoma in Situ Occurred in the External Auditory Canal
}

\author{
Seok Jung Hong, Moon Seung Baeg, Ji Hye Rhee, and Hyun Sang Cho \\ Department of Otorhinolaryngology-Head and Neck Surgery, Veterans Health Service Medical Center, Seoul, Korea
}

외이도에 발생한 편평세포상피내암종 1예

홍석정· 백문승·이지혜· 조현상

중앙보훈병원 이비인후-두경부외과

\author{
Received April 25, 2019 \\ Revised June 2, 2019 \\ Accepted July 17, 2019 \\ Address for correspondence \\ Hyun Sang Cho, MD \\ Department of Otorhinolaryngology- \\ Head and Neck Surgery, \\ Veterans Health Service Medical Center, \\ 53 Jinhwangdo-ro 61-gil, \\ Gangdong-gu, Seoul 05368, Korea \\ Tel $+82-2-2225-4369$ \\ Fax $+82-2-2225-1385$ \\ E-mailent-cho@nate.com
}

Primary malignant lesions in the external auditory canal are rare. While squamous cell carcinoma is the most common of these lesions, there are also basal cell carcinoma, malignant melanoma and adenocarcinoma, etc. However, squamous cell carcinoma in situ of the external auditory canal is extremely rare since its first report in the English literature in 1953 and has not been reported in Korea. Its clinical manifestations are very similar to chronic ear disease. For treatment, local wide resection of the lesions is preferred. We recently encountered a 54-year-old female, who presented with intermittent irritating sensation in the external auditory canal. Otoscopic examination showed a scaly plaque with the irregular surface on the anteroinferior portion of the left external auditory canal. Excisional biopsy revealed a squamous cell carcinoma in situ. We report this very rare and unique case with a literature review.

Korean J Otorhinolaryngol-Head Neck Surg 2020;63(4):176-9

Key Words Carcinoma in situ $\cdot$ External auditory canal $\cdot$ Human papillomavirus.

\section{서 론}

외이도에서 발생하는 악성 종양은 인구 10 만 명당 0.08 명 에서 0.1 명의 비율로 발생할 정도로 드문 질환으로 병리학적 으로는 편평세포암(squamous cell carcinoma)이 82\%로 가 장 많은 비율을 차지하며 이 외에 기저세포암종, 악성 흑색 종, 선암종 등이 있다.) 편평세포상피내암종(squamous cell carcinoma in situ)은 신체의 어느 부위에서나 발생하지만, 주로 체간이나 외음부에 호발한다.2) 외이도에서 편평세포상 피내암종이 발생한 경우는 영문 논문에서 현재까지 3차례만 보고될 정도로 매우 드물게 알려져 있다. ${ }^{3-5}$ 저자들은 수 년 간 지속되어온 좌측 외이도의 이물감을 주소로 내원한 54세 여자 환자를 좌측 외이도 편평세포상피내암종 진단하에 치

This is an Open Access article distributed under the terms of the Creative Commons Attribution Non-Commercial License (https://creativecommons.org/licenses/by-nc/4.0) which permits unrestricted non-commercial use, distribution, and reproduction in any medium, provided the original work is properly cited.
료하였다. 국내에서는 아직 보고된 바 없는 매우 드문 증례 를 체험하였기에 문헌고찰과 함께 보고하고자 한다.

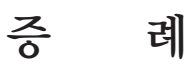

54세 여자 환자가 내원 수 년 전부터 지속되어온 좌측 외 이도의 이물감을 주소로 본원 이비인후과에 내원하였다. 환 자는 간헐적으로 좌측 외이도의 이루가 동반되기도 한다고 호소하였으나, 내원 당시에 이루는 없었고, 청력 저하 및 이 통 등 다른 이과적인 동반 증상은 없었다. 자궁경부 상피내암 으로 2001년 타 병원에서 복강경하 자궁적출술을 시행받았 고, 2016년 본원 산부인과에서 외음부에 콘딜로마 치료력이 있었으며 음주 및 흡연력은 없었다.

내원 시 이학적 검사에서 양측 이개와 고막은 정상 소견이 었으나, 좌측 외이도 연골부 전하벽에 경계가 불명확한 가피 와 인설로 덮인 갈색의 과각화성 병변이 관찰되었다(Fig. 
1A). 정확한 진단을 위해서 외래에서 국소마취하에 생검을 시행하였고, 조직검사상 편평세포상피내암종으로 진단되어, 다른 날 전신마취하에 국소 광범위 절제술 및 피부이식을 계 획하였다. 수술 전 시행한 측두골 전산화단층촬영 및 측두 골 자기공명영상촬영상에서는 병변이 명확하게 구분되지 않 았고 병변 주위로도 특이사항은 관찰되지 않았다(Fig. 1B and C). 수술은 경외이도로 접근하여 병변 주위에 $5 \mathrm{~mm}$ 절 제연을 두고 절개를 가하였고, 깊이는 연골막 윗쪽으로 박리 하여 병변 부위를 완전 절제하였다. 병변 제거 후 결손 부위 를 재건하기 위해 좌측 후이개 피부에서 $2.0 \times 1.0 \mathrm{~cm}$ 크기의 부분층 피부이식편(split thickness skin graft)을 채취하여 외이도의 결손 부위에 이식하였다. 절제 변연부에서 시행한
동결 절편검사는 음성이었고, 조직병리학적 검사에서 기질 침범이 없으며 표피 전층에 걸쳐 비정형적인 편평상피세포로 이루어져 있는 편평세포상피내암종으로 최종 진단되었다 (Fig. 2). 수술 후 환자는 이전에 호소하였던 외이도 이물감 및 이루 증상이 소실된 상태로 18 개월째 재발 소견 없이 외 래 추적 관찰 중에 있다(Fig. 3).

\section{고 찰}

보웬병(Bowen's disease)이라고도 불리는 편평세포상피내 암종은 침습성이 없는 표피 전층의 이형성을 특징으로 하며, 편평세포암의 전구형태이다. ${ }^{3)}$ 외이도 편평세포상피내암종의
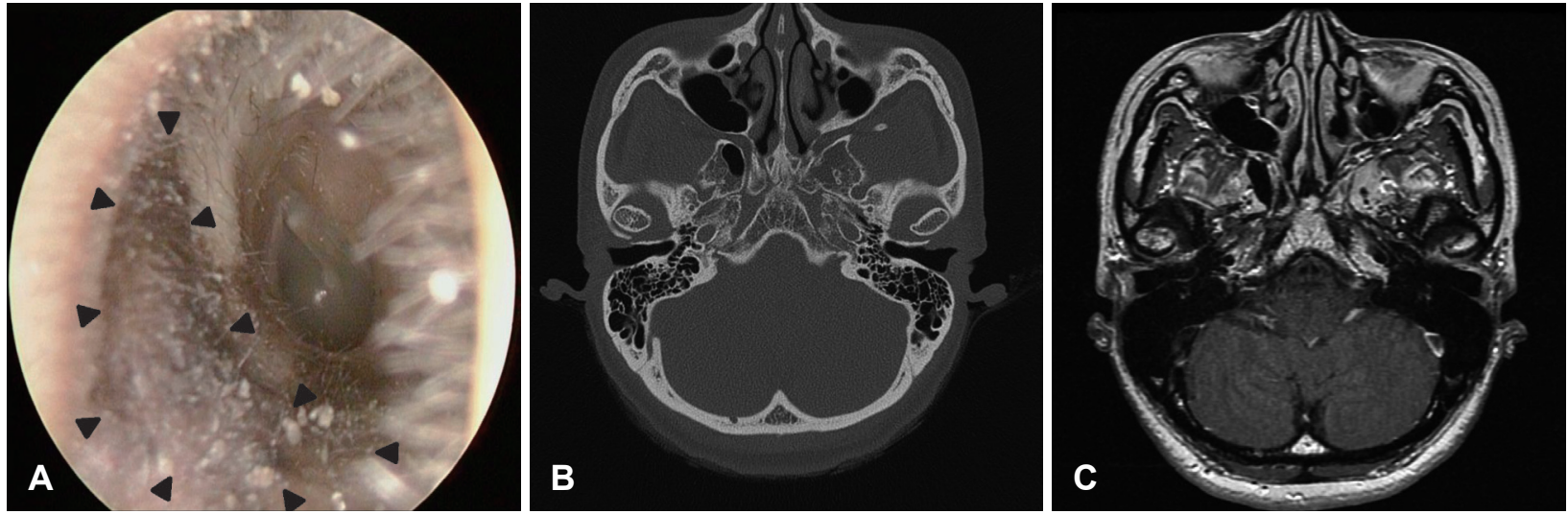

Fig. 1. Preoperative oto-endoscopic finding of the external auditory canal and radiologic findings. A brownish hyperkeratotic scaly plaque with irregular border (arrowheads) is observed in anteroinferior portion of the left external auditory canal (A). Axial image of CT and contrast-enhanced T1-weighted axial MRI shows no critical lesion at the same location (B and C).
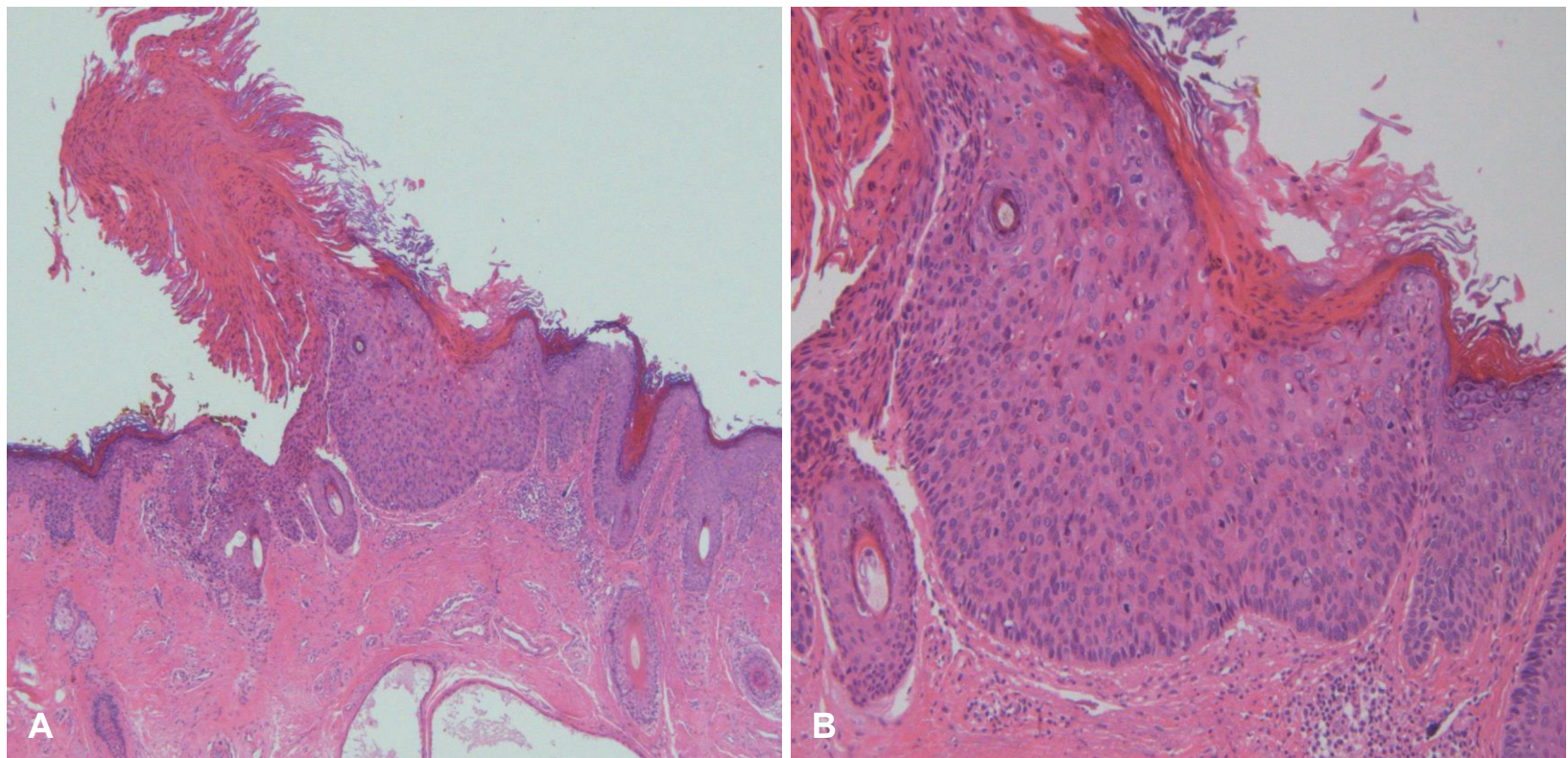

Fig. 2. Histopathologic findings. In low power view, acanthotic squamous epithelial cells show cytologic atypia in full thickness with cutaneous horn formation $(\mathrm{H} \& \mathrm{E}$ stain, $\times 40)(\mathrm{A})$. In high power view, whole layered atypical squamous epithelial cells without stromal invasion is observed (H\&E stain, $\times 200)(B)$. H\&E: hematoxylin and eosin. 


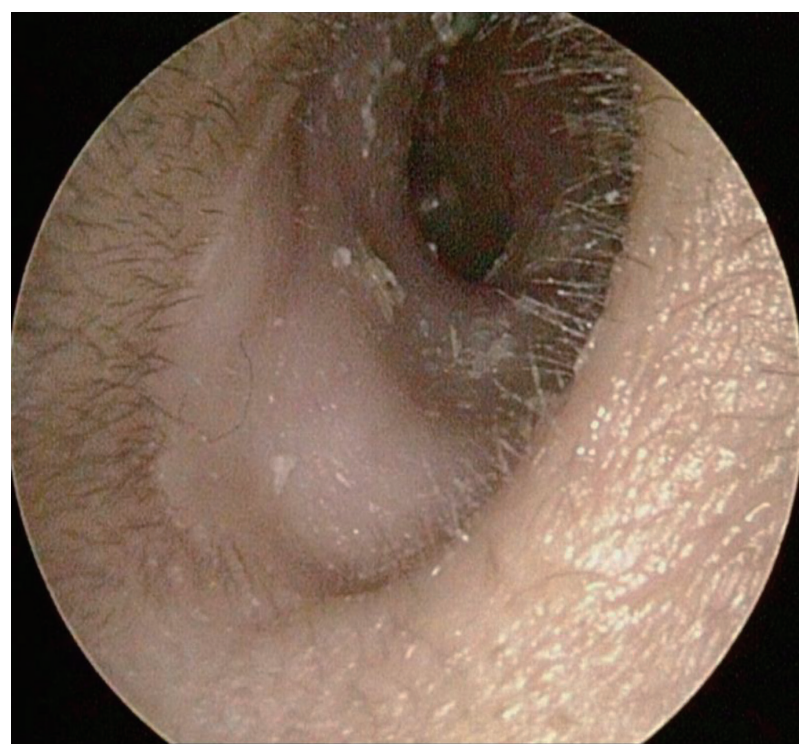

Fig. 3. Postoperative oto-endoscopic finding. There is no evidence of local recurrence in the external auditory canal after 18 months.

발생원인은 불명확하지만, 아스페르길루스(aspergillus)와 녹 농균(pseudomonas)에 의한 만성 감염, 인간유두종바이러스 (human papillomavirus, HPV), 지속적인 자외선 노출 등이 유발인자로 추정된다. ${ }^{2,4}$ 특히, 편평세포상피내암종은 자외선 노출과 상당한 관련성이 있고, HPV 16에 감염된 환자의 83\%에서 발견되기도 한다.)

$\mathrm{HPV}$ 는 주로 여성의 질 안에 기생하는 바이러스로, 일반 적으로 자궁 경부암을 일으키는 주요 원인으로 알려져 있고, 발병 기전에 관여하는 정도가 명확하지는 않지만, 음부 외에 서 발생하는 경우도 있다. ${ }^{78)} \mathrm{HPV}$ 는 게놈의 특정 염기서열에 따라 '형(type)'으로 분류되며 발견된 순서대로 숫자가 정해 진다.9) 이 중 저위험(low risk)형은 양성 혹은 저등급 자궁경 부세포 이상, 생식기 사마귀 및 재발성 호흡기 인유두종증을 일으키며 $6,11,40,42,43,44,54$ 형 등이 있다. 고위험(high risk)형은 자궁경부암과 항문생식기암의 전구인 저등급과 고 등급 자궁경부세포 이상을 일으키며 $16,18,31,33,35,39$, $45,51,52,56,58$ 형 등이 있다. ${ }^{10)}$ 가장 흔한 형은 HPV 16 과 $\mathrm{HPV} 33$ 이지만, 이 외에 다른 형인 HPV $6,52,56,58,59$ 도 드물게 있다. ${ }^{7)}$ 이개는 자외선에 쉽게 노출될 수 있는 신체 부 위이고 이개에 편평세포상피내암종이 발생하는 경우는 비교 적 알려져 있다. 외이도 부위는 이개와 달리 상대적으로 자 외선 비노출 부위임에도 불구하고, 본 증례 환자의 경우에는 외이도 안에 편평세포상피내암종이 발생하였다. 그렇기 때문 에 자외선의 지속적인 노출이 외이도의 편평세포상피내암종 을 유발하였을 가능성은 낮을 것으로 보인다. 환자는 타 병 원에서 자궁적출술을 받았었고, 본원 산부인과에서 자궁경 부 저등급 편평상피내 병변(low grade squamous intraepi- thelial lesion)과 좌측 외음부에 콘딜로마로 치료 중이었던 점에 착안하여, 이비인후과 외래에서 생검한 결과를 확인한 이후 완전절제한 외이도 검체조직에서 HPV genotying을 하 여 결과를 얻었다. HPV 감염은 생식기 접촉, 특히 성교에 의 해 전염되며 가장 중요한 위험인자는 성 활동, 특히 성 파트 너의 수이고, 다른 위험요인으로는 면역상태와 파트너의 성 행동 등이 있다. ${ }^{11)} \mathrm{HPV}$ 가 성 활동에 의해 전염되므로 $\mathrm{HPV}$ 의 역학을 고려할 때, 환자의 성적 행동을 통한 경로로 외이 도에도 감염된 것으로 보인다. 따라서, 본원에서의 검사상 외 이도 병변에서 HPV $6,39,40,51,53,61$ 이 확인되었던 점으 로 HPV가 본 증례 환자의 외이도 편평세포상피내암종 발생 원인으로 추정해 볼 수 있다.

국외에서 앞서 3 차례 보고되었던 외이도 편평세포상피내 암종 환자들의 임상증상으로는 이통, 소양감 및 혈성 이루였 다. 본 증례 환자의 경우는 외이도의 국소적인 이물감과 간헐 적인 이루 증상이었다. 비교적 경한 증상이었기에 재발하는 이루가 있을 경우에만 타 병원에서 한두 차례 염증에 대한 치료만 받으면서 지냈기 때문에 병변에 대한 정확한 진단이 조기에 이루어지지 않았다. 외이도 편평세포상피내암종의 이 학적 소견은 외이도의 표면이 불규칙하게 융기되어 있거나 때로는 가피나 인설로 덮히고, 병변이 커지면서 궤양화되거 나 육아조직이 동반될 수도 있다.) 따라서 통상적인 치료에 반응하지 않거나 비정상적인 외이도 병변과 연관된 만성 염 증 소견이 있는 경우 조직검사를 항상 고려해야 한다. 편평세 포상피내암종의 조직학적 소견은 다양한 크기와 모양의 표 피세포들이 표피 전층에 걸쳐 무질서하게 배열되어 있으며, 편평상피의 극세포화와 이상각화증이 관찰되나 표피와 진피 의 경계는 잘 보존되어 있다. ${ }^{2}$ 하지만, 비교적 크기가 크고 비전형적인 종양세포가 표피와 진피의 경계를 침습하게 되면 편평세포암으로 진단하게 된다. ${ }^{2,6}$

편평세포상피내암종의 대략 $10 \%$ 에서 침습적인 편평세포 암으로 진행하는 것으로 알려져 있어 치료는 완전한 외과적 절제가 이루어져야 한다.) 일반적으로 변연부를 포함한 광범 위 절제술이면 충분하며, 병변이 작은 경우 단순 원형 절제 술을 시행한다. ${ }^{2,4)}$ 본 증례의 환자는 완전한 외과적 절제 및 부분층 피부이식으로 이전에 호소하였던 외이도 이물감 및 이루 증상이 소실된 상태로 18 개월째 재발 소견 없이 외래 추적 관찰 중에 있다. Propylene glycol 등의 5-fluoruracil 항암화학물질의 국소 투여는 피부에서 발생한 경우에는 어 느 정도 효과가 있는 것으로 보고되고 있지만, 외이도에서의 효과는 미지수이다. ${ }^{3)}$

외이도에 발생한 편평세포상피내암종은 국내에서 첫 증례 보고이다. 외이도는 이경이나 이내시경을 통하여 쉽게 관찰할 
수 있는 부위로 외이도염에 준한 일반적인 치료에 반응하지 않는 외이도 병변에 대해서는 진단과 치료가 늦어지지 않도록 조기에 조직검사를 통하여 적극적인 치료계획을 세우는 것이 중요하다. 이전 국외에서 발표된 3차례의 보고들과 본 증례를 통하여 보건대, 외이도에 인설이나 가피로 덮이면서 표면이 불 규칙하게 융기된 소견이 보인다면 드문 발병률로 나타나는 질 환이지만 편평세포상피내암종의 가능성도 염두에 두어야 하 겠다. 또한 HPV와 외이도 편평세포상피내암종의 연관 가능성 이 있으므로 추후 HPV의 형과 관련된 질병의 경과, 치료 및 예후 등에 대해서 추가적인 연구가 진행되어야 할 것이다.

\section{Author Contribution}

Conceptualization: Hyun Sang Cho. Data curation: Hyun Sang Cho, Seok Jung Hong. Formal analysis: Seok Jung Hong. Investigation: Hyun Sang Cho, Moon Seung Baeg. Methodology: Hyun Sang Cho, Seok Jung Hong. Project administration: Hyun Sang Cho. Resources: Moon Seung Baeg. Supervision: Hyun Sang Cho. Validation: Ji hye Rhee. Visualization: Seok Jung Hong, Moon Seung Baeg. Writing_original draft: Seok Jung Hong. Writing_review \& editing: Hyun Sang Cho.

\section{ORCID}

Hyun Sang Cho https://orcid.org/0000-0003-3411-544X

\section{REFERENCES}

1) Jung SH, Kim CW, Kim HS, Lee WS. Squamous cell carcinoma of the external auditory canal: Treatment results of 15 cases. Korean J
Otolaryngol-Head Neck Surg 2005;48(2):136-41.

2) $\mathrm{Kim} \mathrm{CH}$, Choi HS, Lee SJ, Mo JY. A case of salvage operation in radiation-failed squamous cell carcinoma transformed from Bowen's disease. Korean J Otolaryngol-Head Neck Surg 2004;47(5):478-82.

3) Sismanis A, Hughes G. Carcinoma in situ of the ear canal. Am J Otol 1980;2(2):158-9.

4) Shu MT, Lin HC, Yang CC, Chang KM. Squamous cell carcinoma in situ of the external auditory canal. J Laryngol Otol 2006;120(8):684-6.

5) Bennett RJ, Davis BT. A case of intra-epidermal carcinoma (Bowen's disease) of external auditory meatus treated by deep X-rays. J Laryngol Otol 1953;67(12):764-7.

6) Oztürkcan S, Oztürkcan S. Dermatologic diseases of the external ear. Clin Dermatol 2014;32(1):141-52.

7) Murao K, Yoshioka R, Kubo Y. Human papillomavirus infection in Bowen disease: Negative p53 expression, not p16(INK4a) overexpression, is correlated with human papillomavirusassociated Bowen disease. J Dermatol 2014;41(10):878-84.

8) Eftekhari H, Gharaei Nejad K, Azimi SZ, Rafiei R, Mesbah A. Bowen's Disease associated with two human papilloma virus types. Acta Med Iran 2017;55(9):594-6.

9) de Villiers EM, Fauquet C, Broker TR, Bernard HU, zur Hausen H. Classification of papillomaviruses. Virology 2004;324(1):17-27.

10) Muñoz N, Bosch FX, de Sanjosé S, Herrero R, Castellsagué X, Shah KV, et al. Epidemiologic classification of human papillomavirus types associated with cervical cancer. N Engl J Med 2003;348(6):518-27.

11) Winer RL, Lee SK, Hughes JP, Adam DE, Kiviat NB, Koutsky LA. Genital human papillomavirus infection: Incidence and risk factors in a cohort of female university students. Am J Epidemiol 2003;157(3):218-26. 